\title{
Z badań nad dziejami oświaty i polskiego życia narodowego na Pomorzu Nad- wiślańskim w XIX i XX wieku. Ksiega Pamiątkowa dedykowana Doktorowi Je- rzemu Szewsowi z okazji 85. rocznicy urodzin, pod red. Lidii Burzyńskiej-Wen- tland, Gdańsk 2010, ss. 440
}

Księgi pamiątkowe to wspaniałe dowody pamięci dla osób w szczególny sposób zasłużonych dla danej społeczności, środowiska, nauki, publicystyki czy sztuki. Ich rolą jest uhonorowanie jednostek, których działalność stanowi autorytet i wzór do naśladowania. Są dowodem na to, że ktoś komu się je dedykuje jest nietuzinkową osobowością, wyrasta ponad przeciętność i cieszy się uznaniem nie tylko wśród współpracowników i kolegów, ale także w szerszym gronie ludzi.

Jedną z takich ksiąg pamiątkowych jest wydana w roku 2010 zbiorowa praca pod red. Lidii Burzyńskiej-Wentland. Księga ta jest dedykowana badaczowi dziejów oświaty na Pomorzu Gdańskim, doktorowi Jerzemu Teofilowi Szewsowi, który niemal całe swoje zawodowe życie związał z pracą naukowo-dydaktyczną historyka oświaty na Uniwersytecie Gdańskim. Z uznaniem należy odnieść się do tego, że trudu wydania tego typu pracy podjęła się była seminarzysta Jubilata, oddając w ten sposób niejako hołd jego pracy i podziękowanie za wieloletni trud, współpracę i opiekę naukową. Zamieszczony w księdze zbiór studiów jest wyrazem pamięci i szacunku nie tylko wielu osób na co dzień współpracujących z osobą Jerzego Szewsa, ale także innych naukowców i badaczy pragnących w ten sposób okazać swoje uznanie i respekt dla jego działalności naukowej.

Zdecydowana większość autorów tej zbiorowej pracy należy do gdańskich środowisk naukowych zarówno świeckich, jak i kościelnych. Wśród autorów znaleźli się też pracownicy naukowi Poznania, Słupska i Łodzi. Wszystkie prace zamieszczone w Księdze cechuje wysoka wartość naukowo-poznawcza i rzetelność w opracowaniu przedstawionego materiału, choć nie zawsze pewna dyscyplina narzucona cezurą chronologiczną i terytorialną. Tytuł zbioru sugeruje bowiem, że wszystkie zamieszczone w nim opracowania będą dotyczyły zagadnień związanych z przemianami oświatowymi i narodowymi, jakie zachodziły na Pomorzu Nadwiślańskim na przestrzeni dwóch minionych wieków, a kilka prac wykracza poza te ramy. Nie umniejsza to jednak ogólnej wartości tej książki.

Cały zbiór podzielony został na pięć bloków tematycznych. Zasadnie w pierwszym z nich dokonano prezentacji dr. J. Szewsa. Zamieszczono tu cztery opracowania poświęcone osobie szanownego Jubilata. Autorem dwóch tekstów jest Józef Żerko, który przedstawił koleje życia Jubilata (napisane w sposób bardzo ciekawy i rzutki) oraz zestawił jego imponujący dorobek. Dwa pozostałe referaty poświęcone osobie J. Szewsa (mimo że także dotyczą dziejów jego życia) mają bardziej osobisty wymiar. Józef Borzyszkowski z sentymentem opowiada o swoich związkach z Jubilatem i mimo że tekst jest utrzymany w podobnym tonie jak J. Żerki, to wnosi nowe informacje dotyczące życia osobistego. W podobnym tonie napisany jest tekst autorstwa Ireny Jabłońskiej-Kaszewskiej, która z nostalgią wspomina, w jaki sposób zetknęła się z J. Szewsem i jakie znaczenie miała ta znajomość dla jej rodziny. 
Największą częścią zbioru jest blok drugi. Zamieszczono w nim osiem obszernych opracowań będących odbiciem zakresu badań, nad którym skupieni są aktualnie ich autorzy. Każde z nich stanowi swoistą całość. Tematycznie oscylują one wokół kwestii wychowania i oświaty nie tylko regionalnej, ale również krajowej. Poza ramy chronologiczne narzucone tytułem wykracza jedna praca - Jacka Taraszkiewicza. Blok otwiera opracowanie Jerzego Tredera - językoznawcy i badacza języka kaszubskiego. Autor ukazał tu jak szeroko zakrojone były badania nad językiem kaszubskim w XIX w. Jak wynika z jego rozważań kaszubska mniejszość etniczna budziła zainteresowanie nie tylko Polaków i Niemców (jako panujących zaborców na Pomorzu), ale również Rosjan, którzy temu poświęcili wiele badań. Tekst napisany jest $\mathrm{z}$ wielką erudycją, udokumentowany bogatą literaturą.

W innym tonie utrzymany jest tekst Krzysztofa Jakubiaka, który podjął się ukazania genezy pedagogiki rodziny. W sposób syntetyczny autor opisuje zmiany i ważne momenty dla wyodrębnienia się nowego podejścia do familiologii zarówno w Polsce, jak i na gruncie europejskim.

Kolejny artykuł w tym bloku, autorstwa Jacka Taraszkiewicza, wnosi nową wiedzę na temat wykorzystywanych w szkołach pijarskich u schyłku XVII i w XVIII w. podręczników do nauki retoryki i ich roli w kształtowaniu wiedzy historycznej uczniów. Autor, analizując treść poszczególnych książek szkolnych pokazuje, że do przekazywania wiadomości historycznych przywiązywano znaczną uwagę. Zauważyć się daje, że w omawianych podręcznikach zamieszczano zarówno informacje z dziejów powszechnych, jak i historii Polski. Sporo miejsca poświęcone było wybitnym wodzom, którzy przyczynili się do rozkwitu Rzeczypospolitej. Takie ujęcie treści służyło zapewne kształtowaniu odpowiednich postaw patriotycznych wśród wychowanków, a przede wszystkim wychowaniu młodego Polaka-obywatela. Artykuł, mimo że nie mieści się w cezurze chronologicznej stanowi bardzo dobre opracowanie. Uznanie budzą wykorzystane do jego napisania źródła.

Witold Molik w swoim artykule opartym na prasie i literaturze ukazał zjawisko wysyłania synów ziemian wielkopolskich do szkół poza granicami zaboru. Takie praktyki miały miejsce na przełomie XIX i XX w., a ich celem było uchronienie polskich dzieci przed nasiloną germanizacją. Autor, analizując zachowane pamiętniki opisał warunki pobytu i nauki w Chyrowie, Charlottenlund i Ettol. Uzupełnieniem tekstu jest ukazanie stosunku lokalnego społeczeństwa do tego rodzaju praktyk, co stanowi doskonałe podsumowanie prowadzonych rozważań. Artykuł jest doskonale przemyślany, napisany przejrzyście, przystępnym językiem.

Bardzo obszerny artykuł autorstwa Stefana Rafińskiego dotyczy nauczania języka polskiego w okresie zaborów w Gimnazjum Chełmińskim. Autor, opierając się na źródłach archiwalnych, opisał podejście polskiego społeczeństwa do kwestii pobierania nauki w ojczystym języku, jego determinację w podejmowaniu działań, a nawet walki o prawo do oficjalnego nauczania języka polskiego w szkole. Uznanie budzą zamieszczone w przypisach biogramy nauczycieli, szczególnie zaangażowanych w obronę polskości oraz uczniów, którzy zdecydowali się zdawać na egzaminie maturalnym język polski. Artykuł bardzo dobrze napisany, udowadniający, że temat ten jest bardzo bliski autorowi.

Ciekawy i dobrze napisany jest też tekst Henryka Porożyńskiego. Pokazane w nim zostały przemiany, jakie zachodziły w organizacji i funkcjonowaniu prywatnej żeńskiej 
szkoły średniej - Miejskiego Gimnazjum, a później Liceum Żeńskiego w Chojnicach. Opisywana placówka rozpoczęła swoją działalność pod koniec lat 60. XIX stulecia. W artykule jednak punkt ciężkości położony jest na jej losy w okresie międzywojennym. Szkoda, że w tytule autor tego nie zaznaczył. Opracowanie ma charakter monograficzny. Ujęte zostały tu wszystkie aspekty funkcjonowania opisywanej placówki. H. Porożyński podpiera się bogatymi źródłami archiwalnymi, w jasny i przejrzysty sposób pokazuje, jak wyglądało życie codzienne w tej chojnickiej szkole dla dziewcząt.

Autorem kolejnego opracowania jest Romuald Grzybowski, doskonały znawca losów instytucji kształcących nauczycieli w Polsce Ludowej. W swoim artykule przedstawił sytuację kadrową w gdańskich liceach pedagogicznych w pierwszym dziesięcioleciu po zakończeniu II wojny światowej. Artykuł ciekawy, dobrze oddający klimat tamtych lat i wpływu ofensywy ideologicznej na funkcjonowanie polskiego szkolnictwa średniego.

Blok drugi zamyka opracowanie Anny Paszkowskiej poświęcone wprowadzaniu w życie reformy szkolnej z 1961 r. w województwie gdańskim. Jest to interesujący artykuł, poparty wieloma danymi liczbowymi z dobrze wyciągniętymi wnioskami z analizowanych źródeł.

Na blok trzeci składa się sześć opracowań oscylujących wokół zagadnień związanych z działalnością instytucji, stowarzyszeń, prasy i Kościoła na Pomorzu Gdańskim. Trzy pierwsze teksty tematycznie związane są z Kościołem katolickim. Pierwsze opracowanie ks. prof. Anastazego Nadolnego to chronologiczny rejestr biskupów chełmińskich począwszy od wieku XV aż po wiek XVIII. Autor, opisując kolejne sylwetki hierarchów kościelnych uwzględnił nie tylko zakres ich działalności duszpasterskiej, ale również pełnione funkcje polityczne i państwowe.

W kolejnym opracowaniu Paweł Śpica, opierając się na artykułach zamieszczonych na łamach „Gazety Grudziądzkiej”, pokusił się o swego rodzaju ocenę środowiska polskich duchownych katolickich oskarżanego o przyczynianie się do germanizacji lokalnego społeczeństwa. Każdy artykuł dotyczący księży polskich został w tekście ciekawie zinterpretowany i skomentowany, co bardzo podnosi rangę opracowania.

Trzeci tekst, tematycznie związany z Kościołem, dotyczy domów dziecka prowadzonych przez zakony katolickie funkcjonujących na Pomorzu Gdańskim w pierwszym piętnastoleciu po II wojnie światowej. Tytuł tego opracowania sugeruje, że w tekście znajdą się informacje o różnych rodzajach placówek opiekuńczych, nie tylko o domach dziecka. Jeżeli na Pomorzu był tylko ten jeden rodzaj placówki opiekuńczej, to należałoby wspomnieć o tym w tekście, albo inaczej doprecyzować tytuł tego referatu. Autor, Andrzej Kołakowski, w swoim tekście wymienia kolejne domy dziecka i krótko je charakteryzuje. Pokazuje też wpływ laicyzacji życia społecznego na odsuwanie Kościoła katolickiego od działalności oświatowo-opiekuńczej. Swoje rozważania autor oparł przede wszystkim na zachowanych materiałach archiwalnych pochodzących z opisywanego okresu, zgromadzonych w istniejących na Pomorzu Gdańskim Żeńskich Domach Zakonnych.

W kolejnym opracowaniu Elżbieta Gorloff podjęła się ukazania działalności kulturalno-oświatowej prowadzonej na Ziemiach Odzyskanych w pierwszych dziesięciu latach po zakończeniu II wojny światowej. Niestety tekst nie jest adekwatny do nadanego mu tytułu. Termin Ziemie Odzyskane odnosi się do przyznanych Polsce w ramach ładu pojałtań- 
skiego terenów obejmujących Wolne Miasto Gdańsk, południową część Prus Wschodnich, większą część Pomorza i Śląska oraz dzisiejszą Ziemię Lubuską. Tymczasem autorka w całym referacie odwołuje się najczęściej do sytuacji, jaka miała miejsce w Lęborku, rzadziej do całego Pomorza, nie wspomina natomiast o działalności kulturalno-oświatowej prowadzonej na innych terenach. Tekst oparty jest na solidnych źródłach archiwalnych, dobrze udokumentowany, szkoda tylko, że tytuł nie został właściwie sformułowany.

Bardzo interesujące opracowanie dotyczące działalności Rosyjskiego Stowarzyszenia Kulturalnego w Gdańsku w latach 1957-1972 zamieściła w zbiorze Lidia BurzyńskaWentland. Do jego napisania autorka wykorzystała niebagatelną liczbę materiałów źródłowych, co sprawia, że tekst ma ogromną wartość poznawczą.

Blok trzeci niniejszego zbioru zamyka praca Andrzeja Koreckiego poświęcona prasie lokalnej powiatu lubawskiego. Autor prześledził inicjatywy wydawnicze podejmowane od połowy wieku XIX do 1939 r. Największy nacisk położył na działalność Wydawnictwa Drwęca, które niejako zdominowało lokalny rynek prasowy w okresie międzywojennym. Opracowanie to wnosi wiele istotnych i nowych informacji, jest doskonałym przyczynkiem do dziejów prasy polskiej w latach 1920-1939.

Na blok czwarty składa się także sześć prac. Są one poświęcone sylwetkom zasłużonych społeczników, naukowców i badaczy. Wszystkie zaprezentowane biogramy choć znacznie wykraczają poza ramy chronologiczne i terytorialne niniejszej Księgi są cennym studium działalności wybitnych jednostek na rzecz rozwoju nauki i krzewienia polskości.

Dwie pierwsze prace poświęcone zostały życiu i twórczości renesansowych profesorów, wykładowców i nauczycieli młodych pokoleń. Teresa Jaroszewska napisała obszerny tekst o Macieju z Miechowa, wybitnym lekarzu, historyku, astrologu, filantropie, rektorze Akademii Krakowskiej i jego dziełu poświęconemu Europie Wschodniej Tractatus de duabus Sarmatiis, Asiana et Europiana. Ukazała rolę tej rozprawy w popularyzacji wiedzy o ówczesnej Polsce i innych ziemiach ,sarmackich” w Europie Zachodniej. Interesująca analiza „traktatu” pozwala zrozumieć, jak wyglądały kwestie polityczne, narodowościowe, wyznaniowe i klimatyczne w opisywanym przez Macieja z Miechowa okresie.

Drugi tekst autorstwa Lecha Mokrzeckiego i Mariusza Brodnickiego poświęcony został jednemu z profesorów Gdańskiego Gimnazjum Akademickiego, Andrzejowi Hojerowi - filozofowi, historykowi, wykładowcy retoryki i greki. Autorzy oprócz sylwetki tego zaangażowanego w sprawy patriotycznego wychowania młodego pokolenia nauczyciela i wychowawcy, dokonali analizy jego bogatego dorobku piśmienniczego.

Cennym przyczynkiem do kreowania obrazu inteligencji polskiej na Pomorzu przełomu XIX i XX stulecia jest opracowanie Cezarego Olbracht-Prondzyńskiego poświęcone historykowi, teoretykowi i liderowi ruchu filomackiego - Janowi Karnowskiemu. Autor, opierając się na licznych materiałach źródłowych szczegółowo, opisał życie i działalność J. Karnowskiego na Pomorzu Gdańskim i na Kaszubach oraz przeanalizował jego dorobek piśmienniczy poświęcony filomatom pomorskim.

Kolejny biogram polskiego dyplomaty, pracownika Ministerstwa Spraw Zagranicznych Stefana Odrowąż-Wysockiego napisał Tadeusz Oracki. Przybliżył on w ten sposób sylwetkę zapomnianego działacza politycznego, redaktora, propagatora i thumacza polskiej literatury w Niemczech. 
Dwa ostatnie biogramy poświęcone zostały współczesnym działaczom regionalnym. Tomasz Maliszewski w swojej pracy podjął się przedstawienia życia i działalności społecznej Narcyza Kozłowskiego - propagatora idei tworzenia uniwersytetów ludowych, publicysty, historyka, nauczyciela i wychowawcy wielu pokoleń młodych ludzi. Autor położył główny nacisk w swojej pracy na związki N. Kozłowskiego z uniwersytetami ludowymi działającymi na Pomorzu w XX w., a swego bohatera pokazał jako gorliwego propagatora idei edukacji dorosłych na obszarach wiejskich.

Natomiast Irena Wohlfeil nakreśliła sylwetkę współczesnego gdańskiego astronoma Leona Wohlfeila. Autorka jest żoną brata Leona, toteż jej tekst ma wymiar raczej osobisty. Jako naoczny świadek pracy zawodowej L. Wohlfeila docenia cierpliwość i ogrom pracy włożony przez szwagra w obserwację plam na Słońcu. Pokazuje specyfikę jego pracy i szacunek, jakim cieszył się w środowisku gdańskich „,badaczy nieba”. Lektura tego biogramu nasuwa spostrzeżenie, że gdyby nie przedwczesna, nagła śmierć (zmarł w wieku 33 lat) L. Wohlfeila, być może dziś Gdańsk mógłby poszczycić się godnym następcą Jana Heweliusza.

Zbiór studiów zamyka blok piąty. Nie jest on na wzór pozostałych bloków zbiorem studiów i opracowań. To ciekawie udokumentowany prywatnymi i rodzinnymi zdjęciami obszerny, pełen osobistych wątków wywiadem z Jubilatem. Wyodrębnienie go jako oddzielnej całości stanowi niejako puentę tej publikacji.

Podsumowując należy stwierdzić, że niniejsza Księga pamiątkowa posiada nie tylko cechy pracy jubileuszowej, ale przede wszystkim naukowej. Zebrane w niej prace wnoszą nowe ustalenia i informacje do dotychczasowej wiedzy. Poziom merytoryczny większości opracowań jest wysoki. Autorzy dysponowali bardzo rozległą wiedzą na temat prezentowanych zagadnień. Czytelnik otrzymuje do rąk pozycję cenną nie tylko dla badaczy dziejów oświaty na Pomorzu Nadwiślańskim, ale również dla całego środowiska historyków edukacji w Polsce. Należy więc gdańskim historykom oświaty pogratulować publikacji, która oprócz funkcji honorowej, poszerza dotychczasową wiedzę, wprowadza do obiegu naukowego nowe fakty, przynosi szereg analiz i hipotez, w ogromny sposób przyczynia się do lepszego poznania dziejów oświatowych Pomorza w XIX i XX w.

Małgorzata Stawiak-Ososińska

(UJK Kielce)

\section{Mirosław Lapot, $Z$ dziejów opieki nad żydowskim dzieckiem sierocym we Lwo- wie (1772-1939), Wydawnictwo Gliwickiej Wyższej Szkoły Przedsiębiorczo- ści, Gliwice 2011, ss. 248}

Nakładem Wydawnictwa Gliwickiej Wyższej Szkoły Przedsiębiorczości ukazała się publikacja Mirosława Łapota zatytułowana $Z$ dziejów opieki nad żydowskim dzieckiem sierocym (1772-1939). Zasługuje ona na uwagę szerokiego grona Czytelników z uwagi na 